\title{
KONVERSI AMPAS BUAH KELAPA SAWIT (Elaeis guineensis Jacq.) MENJADI ARANG DAN KOMPOS SERTA PENGGUNAANNYA SEBAGAI SOIL CONDITIONING
}

\author{
Sri Setiawaty ${ }^{1^{*}}$, Ratih Permana Sari ${ }^{2}$ \\ ${ }^{1}$ Program Studi Pendidikan Kimia, FKIP Universitas Malikussaleh \\ Jln. Cot Tengku Nie, Reuleut, Muara Batu, Aceh Utara \\ ${ }^{2}$ Program Studi Pendidikan Kimia, FKIP Universitas Samudra \\ Jln. Kampus Meurandeh, Langsa - Aceh 24416 \\ *Email: sri.setiawaty@unimal.ac.id
}

\begin{abstract}
Abstrak
Ampas buah kelapa sawit termasuk salah satu limbah padat yang dihasilkan oleh industri pengolahan kepala sawit yang mengandung selulosa, abu, hemiselulosa, dan lignin, yang pemanfaatannya belum maksimal. Pengolahan ampas buah kelapa sawit sebagai arang, kompos, dan soil conditioning dapat menambah nilai ekonomi. Penelitian ini bertujuan untuk menentukan karakteristik arang dan kompos dari ampas buah kelapa sawit menjadi campuran media tanam sesuai persyaratan SNI. Penelitian ini dilakukan dengan cara mencacah ampas sabut kelapa sawit yang sebagian dijadikan arang dan sebagian lagi dijadikan kompos. Hasil penelitian menunjukkan bahwa arang yang dihasilkan diperoleh rendemen rata-rata sebesar 31,67\%; kadar air 81,14\%; abu 13,87\%; zat mudah menguap 38,45\%; karbon terikat 39,54\%. Pengomposan dilakukan dengan bantuan biodekomposer EM-4. Selama 30 hari pengomposan diperoleh data perubahan suhu rata-rata berkisar antara $30-43^{\circ} \mathrm{C}$. pH rata-rata berkisar antara 6,97-7,00 dan penyusunan bobot rata-rata kompos yaitu $31,55 \%$. Hasil karakterisasi kompos $(\mathrm{C}, \mathrm{N}, \mathrm{P}$, dan $\mathrm{K})$ dan rasio $\mathrm{C} / \mathrm{N}$ rata-rata yaitu: $\mathrm{C}=2,20 \%$; $\mathrm{N}=0,14 \% ; \mathrm{P}=12,41 \% ; \mathrm{K}=0,48 \%$; rasio $\mathrm{C} / \mathrm{N}=15,84$. Uji respon pertumbuhan media tanam campuran arang-kompos terhadap tanaman Caladium bicolour menunjukkan pertambahan tinggi dan daun secara intensif. Hal ini berarti pencampuran arang dan kompos sebagai media tanam dapat meningkatkan hara sehingga dapat memberikan sinergi positif.
\end{abstract}

Kata Kunci: Ampas sabut kelapa sawit, arang, kompos, media tanam, rasio C/N.

\begin{abstract}
Palm oil pulp is a solid waste produced by the palm oil processing industry containing cellulose, ash, hemicellulose, and lignin, the utilization of which has not been maximized. Processing of oil palm pulp as charcoal, compost, and soil conditioning can add economic value. This study aims to determine the characteristics of charcoal and compost from oil palm fruit pulp into a mixture of planting media according to SNI requirements. This research was carried out by chopping the pulp of palm oil which is partly made into charcoal and partly made into compost. The results showed that the charcoal produced obtained an average yield of 31.67\%; water content $81.14 \%$; ash $13.87 \%$; volatile substances $38.45 \%$; carbon bonded $39.54 \%$. Composting is carried out with the help of EM-4 biodecomposer. During 30 days of composting the data obtained an average temperature change ranging from 30-430C. The average $\mathrm{pH}$ is between 6.97-7.00 and the compost average weighting is $31.55 \%$. The results of compost characterization $(C, N, P$, and $K)$ and the average $C / N$ ratio are: $C$ $=2.20 \% ; N=0.14 \% ; P=12.41 \% ; K=0.48 \% ; C / N$ ratio $=15.84$. Test the growth response of the mixed-compost charcoal growing media to the Caladium bicolour plant showed intensive height and leaf growth. This means that mixing charcoal and compost as a planting medium can increase nutrients so that they can provide positive synergy.
\end{abstract}

Keywords: Palm fiber pulp, charcoal, compost, planting media, $C / N$ ratio. 


\section{PENDAHULUAN}

Kelapa sawit memiliki berbagai potensi untuk dikembangkan. Dengan adanya peningkatan perkembangan pabrik kelapa sawit, menyebabkan semakin meningkat pula hasil buangan dari pengolahan pabrik tersebut. Untuk itu hasil pembuangan pabrik kepala sawit perlu dikelola dengan baik, karena mengandung bahan organik yang dapat dimanfaatkan dan agar tidak menurunkan kualitas lingkungan antara lain pencemaran tanah, air dan udara. Salah satu cara pengurangan dampak pencemaran lingkungan oleh limbah kelapa sawit yaitu dengan memanfaatkan limbah tersebut.

Salah satu teknologi alternatif untuk memanfaatkan limbah biomasa ini diantaranya adalah pembuatan arang dari ampas buah kelapa sawit. Arang yang dihasilkan diolah lebih lanjut menjadi produk ekonomis seperti arang aktif, briket arang, serat karbon, arang kompos, dan dapat digunakan secara langsung sebagai soil conditioning (media tanam) melalui teknologi yang aplikatif untuk menjadi produk yang lebih bermanfaat sehingga mudah untuk disosialisasikan ke masyarakat pengguna.

Secara morfologis struktur dari arang terdapat pori yang mampu mengikat dan menyimpan hara tanah. Oleh sebab itu aplikasi arang pada lahan-lahan terutama lahan miskin hara dapat membangun dan meningkatkan kesuburan tanah, karena dapat meningkatkan sirkulasi udara dan air tanah, $\mathrm{pH}$ tanah, dan menyerap kelebihan $\mathrm{CO}_{2}$ tanah, sehingga dapat meningkatkan produktivitas lahan dan hutan tanaman.

Pemanfaatan lainnya dari limbah kelapa sawit yaitu, digunakan sebagai pupuk organik seperti kompos. Pada dasarnya kompos dapat meningkatkan kesuburan kimia dan fisik tanah yang selanjutnya akan meningkatkan produksi tanaman. Selain itu, kompos dapat membuat rasa buah-buahan lebih enak, lebih harum, dan lebih masif. Hal inilah yang mendorong penggunaan pupuk organik, daripada menggunakan pestisida dan pupuk kimia anorganik.

Pemanfaatan limbah kelapa sawit tersebut sebagai alternatif pupuk organik juga memberikan manfaat lain dari sisi ekonomi. Pemupukan di perkebunan kelapa sawit selama ini masih menggunakan pupuk anorganik. Bagi perkebunan kelapa sawit, ini dapat menghemat penggunaan pupuk sintetis sampai dengan 50\%. Penggunaan kompos sebagai pupuk organik akan menghasilkan produktivitas yang terbatas, dan penggunaan pupuk buatan saja (urea, SP, MOP, NPK) juga akan memberikan produktivitas yang terbatas. Maka pemberian arang sebagai campuran kompos akan memberikan sinergi positif karena arang dapat berperan sebagai pensubtitusi pupuk organik kompos yang dapat meningkatkan unsur hara bagi pertumbuhan tanaman.

\section{METODOLOGI PENELITIAN}

Bahan penelitian ini adalah ampas buah kelapa sawit, serbuk gergaji sebagai bahan bakar, biodekomposer EM-4, tanaman keladi hias, tanah serta bahan kimia untuk karakterisasi.

Pada pembuatan arang, ampas buah kelapa sawit dikeringkan dan ditentukan kadar airnya. Proses pengarangan berlangsung selama 4 jam hingga terkarbonisasi (terarang dengan baik). Selanjutnya arang yang dihasilkan dihitung rendemennya dan dikarakterisasi yang meliputi kadar air, kadar abu, kadar zat mudah menguap, dan kadar karbon terikat.

Untuk proses pembuatan kompos, ampas buah kelapa sawit dicacah halus dengan ukuran $2 \mathrm{~cm}$ dan ditentukan kadar air serta dihitung rasio $\mathrm{C} / \mathrm{N}$. Pengamatan 
parameter suhu dan $\mathrm{pH}$ dilakukan setiap hari selama pengomposan sampai kondisi mencapai keadaan stabil. Suhu dipertahankan berkisar antara $40-50^{\circ} \mathrm{C}$.

Selanjutnya ditimbang bobot bahan dilakukan pada hari ke 0, 5, 10, 15, 20, 25, dan 30. Setelah bahan menjadi bokashi, drum plastik dibuka. Bokashi yang telah matang memiliki ciri-ciri berwarna hitam, gembur, tidak panas, dan tidak berbau. Kompos bokashi dihasilkan dianalisis kandungan unsur haranya yang meliputi, kadar C, N, P, dan K.

Arang yang diperoleh selanjutnya menjadi campuran kompos bokashi sebagai media tanam, dan ditentukan kadar air nya serta kandungan unsur haranya yang meliputi, $\mathrm{C}, \mathrm{N}, \mathrm{P}, \mathrm{K}$, dan rasio $\mathrm{C} / \mathrm{N}$. Kemudian diuji respon pertumbuhan terhadap tanaman Caladium Bicolour dengan ulangan sebanyak 3 kali.

\section{HASIL DAN PEMBAHASAN}

Hasil dalam penelitian ini berupa karakteristik arang, kompos, dan media tanam. Hasil penelitian dan pembahasan akan diuraikan sebagai berikut.

\section{Karakteristik Arang}

Karakteristik prosespengarangan/ pirolisis bahan baku ampas buah kelapa sawit pada penelitian ini menggunakan reaktor drum dengan kapasitas sekitar $1 \mathrm{~kg}$ bahan serta dilakukan ulangan sebanyak 3 kali selama 3 jam. Data hasil pirolisis ampas buah kelapa sawit disajikan pada tabel 1 berikut ini.

Tabel 1. Karakteristik arang hasil pirolisis

\begin{tabular}{cccccc}
\hline \multirow{2}{*}{ Ulangan } & \multicolumn{5}{c}{ Kadar (\%) } \\
\cline { 2 - 6 } & Rendemen & Air & $\begin{array}{c}\text { Zat mudah } \\
\text { menguap }\end{array}$ & Abu & $\begin{array}{c}\text { Karbon } \\
\text { terikat }\end{array}$ \\
\hline 1 & 30,00 & 8,18 & 39,66 & 13,84 & 38,32 \\
2 & 35,00 & 8,10 & 35,97 & 13,50 & 42,43 \\
3 & 30,00 & 8,15 & 39,72 & 14,27 & 37,86 \\
Rataan & 31,67 & 8,14 & 38,45 & 13,87 & 39,54 \\
SNI $^{*}$ & - & 6,00 & 30,00 & 4,00 & 60,00 \\
\hline
\end{tabular}

Sumber: Data penelitian, dianalisis di laboratorium kimia, Balai Riset dan Standardisasi Industri Banda Aceh

${ }^{*}$ Standar Nasional Indonesia untuk arang kayu, SNI 01-1682-1996

a. Kadar karbon terikat

Komponen terbesar pada arang adalah karbon yang terbentuk akibat proses pembakaran. Syarat umum arang megandung karbon sebesar $70-80 \%$ dari total arang. Namun, pada hasil pirolisis seperti yang tertera pada tabel 1 kadar karbon terikat yang diperoleh rata-rata hanya $39,54 \%$. Hal ini disebabkan oleh nilai kadar abu dan zat mudah menguap yang diperoleh sangat tinggi, karena kadar karbon terikat diperoleh dari hasil pengurangan kadar air, abu, dan zat mudah menguap.

Selain faktor tersebut diatas, karena kadar karbon terikat juga dipengaruhi oleh suhu akhir lama pengarangan, ukuran bahan dan berat jenis. Suhu akhir dan waktu proses pengarangan sangat mempengaruhi, karena suhu akhir yang tidak terlalu tinggi akan diperoleh asam dan alkohol serta gas dan arang yang belum bak. Oleh karena itu, untuk memperoleh arang yang baik 
yang diperlukan pada suhu $500^{\circ} \mathrm{C}$

\section{b. Kadar Abu}

Abu merupakan residu pembakaran dari senyawa anorganik yang terdiri atas $\mathrm{O}_{2}, \mathrm{MgO}, \mathrm{Na}_{2} \mathrm{O}, \mathrm{K}_{2} \mathrm{O}_{2}$, dan $\mathrm{TiO}_{2}$. Pada tabel 1 diperoleh kadar abu rata-rata $13,87 \%$. Arang dengan kadar abu yang tinggi pada perlakuan disebabkan bahan baku ampas kelapa sawit berbentuk serpihan mempunyai jumlah luas permukaan yang lebih besar, sehingga pada proses karbonisasi bahan lebih cepat terbakar yang akhirnya banyak zat-zat yang hilang dan menyebabkan kadar abu naik.

c. Kadar zat mudah menguap

Persentase kadar zat mudah menguap meningkat dengan diikutii menurun persentase kadar abu dan karbon terikat. Waktu yang digunakan saat proses pirolisis berpengaruh terhadap zat mudah menguap, yaitu semakin lama proses pirolisis berlangsung maka semakin banyak komponen senyawa lain yang ikut menguap. Dalam penelitian ini, waktu yang digunakan adalah 3 jam. Oleh karena itu, masih banyak terdapat komponen senyawa lain yang terikat pada arang. Sehingga kadar zat mudah menguap yang dihasilkan sangat tinggi, yaitu rata-rata berkisar $38,45 \%$.

\section{Karakteristik Kompos}

Pengomposan ampas buah kelapa sawit pada penelitian ini secara umum berlangsung selama \pm 30 hari, dan selama proses tersebut terjadi perubahan sifatsifat bahan, antara lain perubahan warna, suhu, pH dan kelembapan. Adapun data perubahan suhu kompos selama proses pengomposan dapat dilihat pada Gambar 1 .

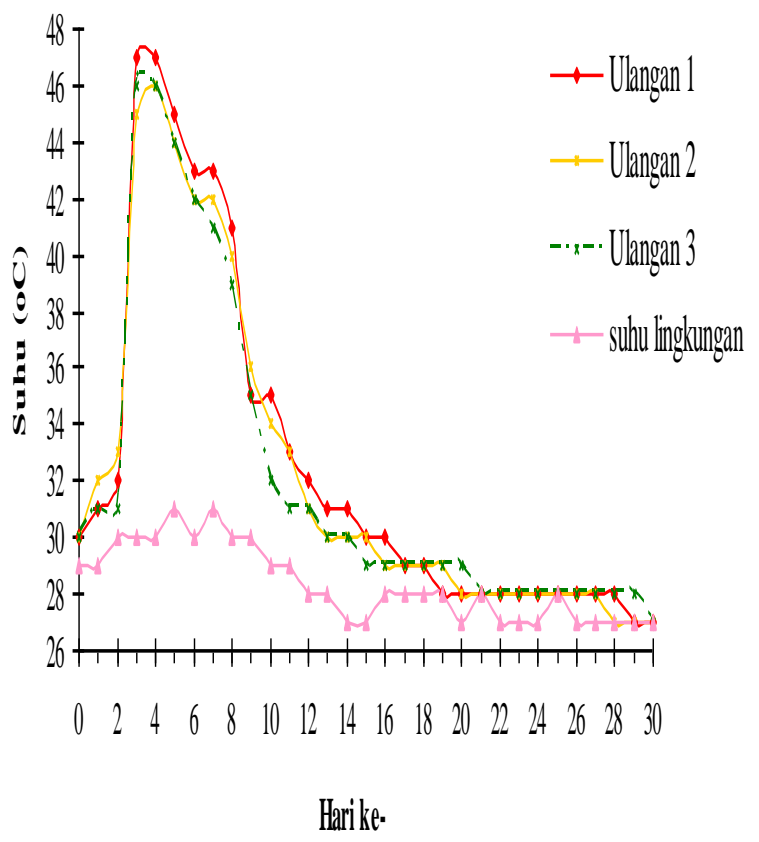

Gambar 1. Grafik perubahan suhu kompos selama pengomposan

Faktor suhu sangat berhubungan dengan proses dekomposisi atau perombakan bahan organik, aktivitas mikroorganisme dan kadar air bahan yang dikomposkan. Menurut Gani (2007:63), Perubahan suhu selama proses pengomposan merupakan salah satu faktor penting sebagai penentu apakah proses dekomposisi berjalan dengan baik atau tidak.

Berdasarkan Gambar 1, menunjukkan adanya proses perubahan suhu selama seminggu pengomposan rata-rata berkisar antara $30-42^{\circ} \mathrm{C}$. Peningkatan suhu disebabkan pada perlakuan digunakan biodekomposer cairan EM-4 yang mengandung bakteri fotosintetik, lactobacillus, actynomycetes, sterpmyces $s p$, dan ragi yang mempercepat perombakan bahan-bahan organik serta relatif dapat bercampur secara lebih homogen dengan bahan-bahan yang dikomposkan sehingga terjadi interaksi sempurna antar komponen untuk meningkatkan energi kinetik pada proses tersebut.

Kualitas suatu kompos juga ditentukan oleh beberapa karakteristik diantaranya, 
yaitu kandungan unsur hara dan tingkat kesempurnaan kompos yang dapat diketahui dengan memperhatikan parameter antara lain rasio $\mathrm{C} / \mathrm{N}$ yang relatif rendah (sesuai dengan rasio $\mathrm{C} / \mathrm{N}$ tanah). Adapun nilai kualitas kompos pada perlakuan selama 30 hari pengomposan disajikan pada tabel 2 berikut.

Tabel 2. Nilai kualitas kompos pada hari ke-30 proses pengomposan

\begin{tabular}{cccccc}
\multirow{2}{*}{ Ulangan } & \multicolumn{5}{c}{ \%Unsur hara kompos } \\
\cline { 2 - 6 } & $\mathrm{C}$ & $\mathrm{N}$ & Rasio C/N & $\mathrm{P}$ & $\mathrm{K}$ \\
\hline 1 & 2,46 & 0,15 & 16,40 & 13,74 & 0,55 \\
2 & 2,12 & 0,14 & 14,36 & 12,62 & 0,40 \\
3 & 2,01 & 0,12 & 16,75 & 10,86 & 0,50 \\
Rataan & 2,20 & 0,14 & 15,84 & 12,41 & 0,48 \\
$\mathrm{SNI}^{*}$ : Minimum & 9,80 & 0,98 & 10,00 & 0,10 & 0,20 \\
Maksimum & 32,00 & - & 20,00 & - & -
\end{tabular}

Sumber: Data penelitian, dianalisis di laboratorium kimia, Balai Riset dan Standardisasi Industri Banda Aceh ${ }^{*}$ Standar Nasional Indonesia untuk kompos, SNI 19-7030-2004

a. Kandungan karbon pada kompos

Kandungan unsur hara kompos sangat menentukan kemampuannya untuk menaikkan kadar unsur hara dalam tanah sehingga dapat menyuburkan tanaman. Tumbuhan tingkat tinggi memperoleh unsur karbon dari udara melalui stomata yang terdapat di permukaan daun dan diproses melalui mekanisme fotosintesis.

\section{b. Kandungan nitrogen pada kompos}

Unsur hara makro adalah unsur hara yang dibutuhkan tanaman dalam jumlah relatif besar. Unsur makro nitrogen adalah komponen utama berbagai substansi penting dalam tanaman. Sekitar 40-50\% kandungan protoplasma yang merupakan substansi hidup dari sel tumbuhan terdiri dari senyawa nitrogen. Senyawa nitrogen digunakan tanaman untuk membentuk asam amino yang diubah menjadi protein dan juga dibutuhkan untuk membentuk senyawa penting seperti klorofil, asam nukleat, dan enzim. Berdasarkan analisis pada tabel 2 kandungan nitrogen pada kompos rata-rata berkisar $0,14 \%$, lebih rendah dari persyaratan standar.

c. Kandungan fosfor pada kompos
Unsur fosfor mempunyai peranan penting dalam proses metabolisme, yaitu anabolisme dan katabolisme karbohidrat, selain itu fosfor juga berperan dalam transformasi energi dalam metabolisme lemak pada tanaman. Fosfor diserap tanaman dalam bentuk $\mathrm{H}_{2} \mathrm{PO}_{4}^{-}, \mathrm{HPO}_{4}{ }^{2-}$ atau tergantung dari nilai $\mathrm{pH}$ tanah atau pun media tanam. Jika terjadi kekurangan fosfor tanaman akan menunjukkan gejala pertumbuhan akar dan buah yang terhambat, daun berwarna hijau tua mengkilap serta pinggiran daun menguning.

\section{d. Kandungan kalium pada kompos}

Unsur kalium diserap oleh tanaman dalam bentuk ion $\mathrm{K}^{+}$. Kalium bersifat mobil (mudah bergerak) sehingga siap dipindahkan dari satu organ ke organ lain yang membutuhkan. Kalium berperan dalam translokasi (pemindahan gula pada pembentukan pati) dan protein serta memproduksi karbohidrat dalam jumlah banyak.

Berdasarkan hasil analisis pada tabel 2 kandungan kalium pada kompos rata-rata berkisar $0,48 \%$. Apabila kandungan yang 
dihasilkan masih kurang maka tanaman akan mengalami gejala defisiensi kalium yang ditunjukkan dengan batang dan cabang lemah dan mudah rebah pada tanaman, daun mengerut (keriting) dimulai dari daun tua, muncul warna kuning di pinggir dan di ujung daun yang sudah tua serta kematangan buah yang terhambat.

\section{Karakteristik Media Tanam}

Secara umum perlakuan penambahan arang dan kompos sebagai media tanam berpengaruh lebih baik pada tanaman dibandingkan perlakuan kontrol. Campuran media tanam ini mampu menambah bahan organik sehingga kandungan unsur hara tanah bertambah. Bahan organik dalam tanah berfungsi untuk memperbaiki sifat fisik tanah seperti struktur tanah, dan sifat kimia tanah seperti kapasitas tukar kation. Adapun nilai kandungan unsur hara pada media tanam arang kompos dapat dilihat pada tabel berikut.

Tabel 3. Nilai kandungan unsur hara pada media tanam arang-kompos

\begin{tabular}{ccccccc}
\hline $\begin{array}{c}\text { Media } \\
\text { tanam }\end{array}$ & $\begin{array}{c}\text { Kadar air } \\
(\%)\end{array}$ & $\mathrm{C}$ & $\mathrm{N}$ & $\begin{array}{c}\text { Rasio } \\
\mathrm{C} / \mathrm{N}\end{array}$ & $\mathrm{P}_{2} \mathrm{O}_{5}$ & $\mathrm{~K}_{2} \mathrm{O}$ \\
\hline $\begin{array}{c}\text { Arang- } \\
\text { kompos } \\
\text { SNI : }\end{array}$ & 8,10 & 19,13 & 0,81 & 23,61 & 0,33 & 0,52 \\
$\begin{array}{c}\text { Minimum } \\
\text { Maksimu } \\
\text { m }\end{array}$ & 6,00 & 9,80 & 0,98 & 10 & 0,10 & 0,20 \\
& - & 32 & - & 20 & - & -
\end{tabular}

Sumber: Data penelitian, dianalisis di laboratorium tanah dan tanaman, Fakultas Pertanian Unsyiah Banda Aceh

Pada uji respon pertumbuhan terhadap tanaman Caladium Bicolour, perkembangan tanaman menunjukkan pertambahan tinggi dan daun secara baik, hal ini berarti pencampuran arang dan kompos yang homogen dapat meningkatkan hara pada media tanam seperti unsur kalium dan fosfor. Peningkatan hara ini memberikan sinergi positif pada pertumbuhan tanaman Caladium Bicolour. Namun, pertumbuhan tanaman tersebut cepat dan menjadi lambat setelah tanaman berumur lebih dari 10 hari. Hal ini dapat disebabkan oleh volume media yang digunakan terlalu kecil sehingga nutrisi pada media tidak mencukupi kebutuhan tanaman, selain itu dapat juga disebabkan oleh tercucinya unsur hara pada saat penyiraman.

\section{KESIMPULAN}

Dari hasil penelitian ini dapat diambil kesimpulan bahwa aplikasi limbah pabrik kelapa sawit dari ampas buah kelapa sawit berupa arang dan kompos dapat meningkatkan kualitas sifat fisik, kimia dan biologi tanah serta pertumbuhan tanaman. Penggunaan campuran arang dan kompos sebagai media tanam dapat meningkatkan juga jumlah kandungan unsur hara berupa unsur karbon dan nitrogen berdasarkan rasio $\mathrm{C} / \mathrm{N}$ yang diperoleh sebesar $23,61 \%$, fosfor sebesar $0,33 \%$ dan kalium $0,52 \%$. Peningkatan unsur hara ini memberikan sinergi positif pada pertumbuhan tanaman yang akhirnya diikuti dengan peningkatan produktivitas tanaman.

\section{DAFTAR PUSTAKA}

Fauzi, Y., Widyadtuti, Y. E., Satyawibawa, 
I., Hartono, R. 2006. Kelapa Sawit, Budidaya, Pemanfaatan Hasil dan Limbah, Analisis Usaha dan Pemasaran. Penebar Swadaya. Jakarta.

Gani, A. 2007. Konversi Sampah Organik Pasar menjadi KOMARASCA (Kompos-Arang-Asap Cair) dan Aplikasinya pada Tanaman Daun Dewa. Disertasi tidak dipublikasikan. Bogor: Sekolah Pascasarjana Institut Pertanian Bogor.

Haji, A. G., Z. A. Mas'ud., B. W. Lay., S. H. Sutjahjo., dan G. Pari. 2006. Karakterisasi Kompos Hasil Dekomposisi Sampah Organik Perkotaan dengan Biodekomposer EM-4, Orgadec, dan Biodek. Enviro Jurnal Ilmiah Lingkungan Hidup. (8):25-32.

Nurhayati, T. 2005. Tempurung Kelapa Sawit (TKS) 